\section{SOI: 1.1 /TAS DOI: $10.15863 /$ TAS International Scientific Journal Theoretical \& Applied Science}

p-ISSN: 2308-4944 (print) e-ISSN: 2409-0085 (online)

Year: $2016 \quad$ Issue: 3 Volume: 35

Published: $30.03 .2016 \quad$ http://T-Science.org

SECTION 23. Agriculture. Agronomy. The technique.

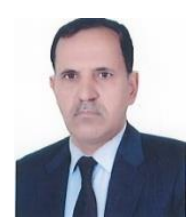

Abbas Mohsin Salman Al- Hameedawi Professor,

College of Agriculture,

University of Kufa. Iraq ali.alhameedawi@uokufa.edu.iq

Wasan Hamza Mezial AL- Shemmeryi Lecturer

College Science, Univ. of Wasst. Iraq

\title{
THE IMPACT OF STICKCHUT AND GROPLANOFIX ON VEGETATIVE GROWTH, YIELD AND FRUIT QUALITY OF FIG TREE CV. ASWOD DIALA
}

\begin{abstract}
This study was conducted during the growing season of 2015 in a private orchard at AL-Abbasyia, Najaf Governorate on the local fig cv. Aswod Diala. The trees were spraying with Stickchut at concentrations of (2 and 4\%) and Groplanofix at conc. of ( 300 and $400 \mathrm{mg} / \mathrm{L}$ ) in single way or incombination at 15 march and 15 May, 2015. Results showed that spraying Stickchut and Groplanofix treatments and their interactions caused a significant increase percentage of leaf moisture, leaf area, shoot length, length of fruit, diameter of fruit, weight of fruit, fruit firmness, percentage humidity of fruits, total yield, and decrease in fruit drops, percentage of fruit cracking, total soluble sold, acidity and Vitamin $C$ of fruits compared with control treatment. There was significant differences between above mentioned treatments. Groplanofix was more effective than Stickchut in that respect, but the combination of Groplanofix and Stickchut gave the best results in the treatment (Stickchut 4\%+ Groplantofix $400 \mathrm{mg} / \mathrm{L}$ ) for the second crop.

Key words: Stickchut, Groplantofix, vegetative growth and quality of fig fruits.

Language: English

Citation: Al-Hameedawi AM, AL-Shemmeryi WH (2016) THE IMPACT OF STICKCHUT AND GROPLANOFIX ON VEGETATIVE GROWTH, YIELD AND FRUIT QUALITY OF FIG TREE CV. ASWOD DIALA. ISJ Theoretical \& Applied Science, 03 (35): 17-20.

Soi: http://s-o-i.org/1.1/TAS-03-35-3 Doi: crossef http://dx.doi.org/10.15863/TAS.2016.03.35.3
\end{abstract}

\section{Introduction}

Many investigators found that antitranspirant agents as pre harvest treatment enhanced percentage of leaf moisture, leaf aria, fruit size and consequently yield of apple ( Hayat, et. al. 2003 ) . AL-Eneabi ( 2008 ) noticed that, the spraying of material wax Vapor-Gard at percentage ( 2,3 and $4 \%$ ) and NAA at concentration ( 25,50 and $75 \mathrm{mg} / \mathrm{L})$ on fig trees cv. Aswod Diala at depressed period reduced the proportion of fruit cracking and increased the length of fruit, diameter of fruit, weight of fruit, fruit firmness, percentage humidity of fruits, total yield, leaf area, total chlorophyll, percentage of carbohydrate. Sabir, et. al. (2004) observed that apple trees when applied at ( 2 and $3 \%$ ) from antitranspirant after 60 days from full bloom increased yield and fruit quality compared with control treatment. AL - Hamdawi et. al. (2014) found that spraying trees of fig $\mathrm{cv}$. Waziri with Grofalcs at concentration of $250 \mathrm{mg} / \mathrm{L}$ at 15 march for the tow growing seasons caused a significant increased total chlorophyll in leaves, total yield of tree, total soluble solids, vitamin $\mathrm{C}$, and fruit firmness and decrease in fruit drupe, fruit cracking compared with control treatment. Abdlecho (2013) noticed that, spraying the local pomegranate trees with Grofalcs at concentrations (200 and $300 \mathrm{mg} / \mathrm{L})$ and wax material Wilt - Pruf at percentage (2 and $4 \%$ ) and combination treatment between them produced increasing significant in the moisture peels , pulp, juice percentage and reducing the cracking, T.S.S, acidity, anthocyanine and vitamin $\mathrm{C}$ in juice during fruits ripening. AL - Ebraheme (2013) noticed that, spraying apple c.v. Read summer tress with two concentration of NAA (25 and 50) $\mathrm{mg} / \mathrm{L}$, and castor oil (2 and 4) \% and combination treatment between them produced increasing significant in the moisture peels , pulp, juice percentage and reducing the cracking, T.S.S, acidity, anthocyanine on peels and Vitamin $\mathrm{C}$ in juice during fruits ripening . $\mathrm{AL}-$ Noumani (2013) found that spraying local apple trees with antitranspirant and Grofalcs $\left(\mathrm{GA}_{3}\right)$ at conc. of ( 200,300 and 400 ) $\mathrm{mg} / \mathrm{L}$ led to reduction in percentage of fruit dropping and cracking and increased total soluble solids, total sugar, vitamin C 
and firmness at ripening. Abo - Zaid (2000) mentioned that, spraying of $\mathrm{GA}_{3}$ at conc. of (100 and $150 \mathrm{ppm}$ ) on pear trees in Egypt has increased the vegetative growth and fruit firmness. The purpose is to study the effect of Stickchut and Groplanofix treatments and their interactions on vegetative growth, yield and fruit quality of local fig tree cv. Aswod Diala .

This study was conducted in a private farm at AL-Abbasyia .Najaf governorate for the 2015 season on local fig tree cv. Aswod Diala , 27 trees at same size and growth were selected with 15 years of age , that planted on $(5 \times 5 \mathrm{~m}$.), they were spraying with tow concentrations ( 2 and $4 \%$ ) of Stickchut ( Candelia E902 material wax contain antioxidant $12 \%$ + di-2-p-menthenne $88 \%$ according to the characteristics of American foods and drags organization ) and Groplanofix ( 300 and $400 \mathrm{mg} / \mathrm{L}$ ) ( It were discs of $\left(\mathrm{GA}_{3}\right.$ and NAA $50 \%$ ) from the production of Green river company. India) in two periods at15 March and 15 May, 2015. The experiment included 9 treatments with three replicates. It is adopted according to Randomized Complete Block Design (RCBD), and the results were statistically analyzed according to LSD test at the probability level of 5\% (Al-Rawi and Khalf Allah, 2000). Trees spraying was done early morning until wetness was full addendum. Tween 20 was added at conc. of $1 \mathrm{~cm}^{3} / \mathrm{L}$ as spreader material. Percentage of leaf moisture, leaf aria $\mathrm{cm}^{2}$, shoot length $\mathrm{cm}, \%$ fruit drup, length of fruit $\mathrm{cm}$, diameter of fruit $\mathrm{cm}$, weight of fruit gm, fruit firmness, percentage, percentage of humidity of fruits, total yield $\mathrm{Kg} /$ tree according to ( Ibrahim, 2010 ) .Firmness was measured on two sides of each fruit with an Effegi penetrometer (Model NI, McCormick Fruit Tech ,Yakima ,WA) Fitted with an $11.1 \mathrm{~mm}$ tip . The percentage of cracking were calculated during the months of Jun and July for season according to (AL - Hmeedawiand AL -Noumani, 2012). The total soluble solids were determined by hand refract meter. Total acidy \% and Vitamin C mg /100 ml Juice according to (A.O.A.C, 1985).

\section{Results and discussion}

1-Leaf moisture, leaf aria, shoot length, length of fruit, diameter of fruit, weight of fruit, firmness of fruit, humidity of fruit and total yield.

The data in table 1 and 2 indicate that Spraying with Stickchut and Groplanofix in single way or combination led to a significant increased in the leaf moisture, leaf aria, shoot length, length of fruit , diameter of fruit, weight of fruit, firmness of fruit ,humidity of fruit and total yield compared to control treatment until reached highest rates ( $78.91 \%$, $125.00 \mathrm{~cm}^{2}, 23.50 \mathrm{~cm}, 4.46 \mathrm{~cm}, 4.95 \mathrm{~cm}, 35.21 \mathrm{gm}$, $0.423 \mathrm{~kg} / \mathrm{cm}^{2}, 80.01 \%$ and $31.48 \mathrm{~kg} /$ tree ) in the treatment ( Stickchut 4\%+ Groplantofix $400 \mathrm{mg} / \mathrm{L}$ ) in comparison to the lowest values $(71.18 \%, 113.21$ $\mathrm{cm}^{2}, 12.37 \mathrm{~cm}, 3.70 \mathrm{~cm}, 4.25 \mathrm{~cm}, 32.70 \mathrm{gm}$, $0.340 \mathrm{~kg} / \mathrm{cm}^{2}, 77.25 \%$ and $22.60 \mathrm{~kg} /$ tree ) in control treatment, respectively. The increase of this characterize of vegetative growth and fruits because of the treatment with concentrations of Stickchut and Groplanofix due to the fact that auxins and gibberellins work as center to aggregation nutrient materials and enhancing the speed of transferring materials from lethatertialsraitrd (ndethbids2003). The increase in firmness in fruits due to spraying trees with auxins and gibberellins because these treatments plays an important role in strengthening the cell walls through its role in enhancing pectin coherence which increases the thickness of cell walls, which makes it more strength and stiffness to resist pectin analysis enzymes Byers and Carbough (1995). Besides that increasing in the fruit length, cell size, leaf aria, total chlorophyll were obtained due to the treated of effect. This act leads to enhance the photosynthesis process and transfer materials to fruits and in large increase in total growth. These result are in line with (AL - Hameedawi, 2015) on apple he mentioned that applying of Tall- prolong to the trees gave the higher growth vegetative and yield compared with control treatment. The increase in total carbohydrates in fruits due to spraying trees with growth regulator led to the effect of these treatments in improvise trees growth i.e. leaf area total chlorophyll of the leaves and absorption of water, nutrition and an increase in food synthesized that trans located to fruits to increasing length of fruit, diameter of fruit, weight of fruit, firmness of fruit, humidity of fruit and total yield ( AL- Uajjani, 2011).

2-The percentage of fruit drop, percentage of fruit cracking, total soluble solids, acidity and vitamin C.

Data in Table ( 2 ) shows that percentage of fruit drop, percentage of cracking, total soluble solids ( T.S.S ) and Vitamin C, in fruits were decreased insignificantly when trees sprayed with Stickchut and Groplanofix. However the differences between treatments in acidity no significant effect for all fruit trees. The highest significance result were recorded in control treatment, that gave the highest percentages of fruit drop, percentage of cracking, total soluble solids and vitamin $\mathrm{C}$, they were $(15.58$ $\%, 14.73 \%, 14.71 \%$ and $7.75 \mathrm{mg} / 100 \mathrm{ml}$ Juice ) comparison with lest rates $(5.90 \%, 6.59 \%, 14.17$ $\%$ and $7.18 \mathrm{mg} / 100 \mathrm{ml}$ Juice ) in control treatment, respectively. The decreasing in the fruit dropping percentage due to auxins spraying could be attributed for prevention cell wall middle lamella analysis in abscission zone through decreasing the action of ethylene, peroxidase and IAA- Oxidase enzymes which resulted in the physiological analysis occurring to the cell wall. Meanwhile the decreasing in cracking percentage due to gibberellins spraying could be attributed to the increase in plasticity and 


\begin{tabular}{|c|c|c|c|c|c|c|}
\hline Impact Factor: & $\begin{array}{l}\text { ISRA (India) } \\
\text { ISI (Dubai, UAE } \\
\text { GIF (Australia) } \\
\text { JIF }\end{array}$ & $\begin{array}{l}=1.344 \\
=0.829 \\
=0.564 \\
=1.500\end{array}$ & $\begin{array}{l}\text { SIS (USA) } \\
\text { PИНЦ (Russia) } \\
\text { ESJI (KZ) } \\
\text { SJIF (Morocco) }\end{array}$ & $\begin{array}{l}=0.912 \\
=0.179 \\
=1.042 \\
=2.031\end{array}$ & $\begin{array}{l}\text { ICV (Poland) } \\
\text { PIF (India) } \\
\text { IBI (India) }\end{array}$ & $\begin{array}{l}=6.630 \\
=1.940 \\
=4.260\end{array}$ \\
\hline
\end{tabular}

elasticity of fruit peel that carried on with internal fruit growth, besides, its role in cell extension and increasing photosynthesis products that has big necessary importance in building cell wall, and strength to protect fruit from cracking ( Byers and Carbough, 1995). The reduction in total soluble solids and vitamin $\mathrm{C}$ due to the sprayed with Stickchut and Groplanofix return to the increase in the percentage of fruit water contents which intern reducing the concentration of materials in fruit juice.

\section{Conclusion}

It could be concluded from this experiment that, spraying fig trees cv. Aswod Diala with Stickchut and Groplantofix led to increased the leaf moisture, leaf area, shoot length, length of fruit, diameter of fruit, weight of fruit, firmness of fruit, humidity of fruit and total yield. Also reduced percentage of fruit drop, percentage of cracking, T.S.S, acidity and vitamin $\mathrm{C}$ of fruits in second crop compared with control treatment.

Table 1

Effect of spraying with Stickchut and Groplantofix and their interaction on vegetative growth and physical characters fruits of local fig cv. Aswod Diala for season 2015.

\begin{tabular}{|l|l|l|l|l|l|l|l|}
\hline Treatments & $\begin{array}{l}\text { \%leaf } \\
\text { moisture }\end{array}$ & $\begin{array}{l}\text { leaf aria } \\
\mathrm{cm}^{2}\end{array}$ & $\begin{array}{l}\text { Shoot } \\
\text { length cm }\end{array}$ & $\begin{array}{l}\% \text { Fruit } \\
\text { drop }\end{array}$ & $\begin{array}{l}\text { Length of } \\
\text { fruit cm }\end{array}$ & $\begin{array}{l}\text { Diameter of } \\
\text { fruit cm }\end{array}$ & $\begin{array}{l}\text { weight of } \\
\text { fruit gm }\end{array}$ \\
\hline \multicolumn{1}{|c|}{ Control } & 71.18 & 113.21 & 12.37 & 15.58 & 3.70 & 4.26 & 32.96 \\
\hline Stickchut 2\% & 73.34 & 114.90 & 12.60 & 13.22 & 3.75 & 4.34 & 33.40 \\
\hline Stickchut 4\% & 74.36 & 115.59 & 12.78 & 12.61 & 3.82 & 4.35 & 33.80 \\
\hline $\begin{array}{l}\text { Groplantofix } \\
\text { 300 mg / L }\end{array}$ & 74.98 & 118.75 & 16.25 & 9.42 & 4.11 & 4.78 & 33.95 \\
\hline $\begin{array}{l}\text { Groplantofix } \\
\text { 400 mg / L }\end{array}$ & 75.40 & 120.64 & 17.88 & 7.70 & 4.18 & 4.80 & 34.04 \\
\hline $\begin{array}{l}\text { Stickchut 2\%+ } \\
\text { Groplantofix } \\
\text { 300 mg / L }\end{array}$ & 75.70 & 120.36 & 17.40 & 8.55 & 4.09 & 4.75 & 33.98 \\
\hline $\begin{array}{l}\text { Stickchut 2\%+ } \\
\text { Groplantofix } \\
\text { 400 mg / L }\end{array}$ & 76.24 & 122.12 & 18.29 & 7.84 & 4.20 & 4.85 & 34.12 \\
\hline $\begin{array}{l}\text { Stickchut 4\%+ } \\
\text { Groplantofix } \\
\text { 300 mg / L }\end{array}$ & 77.78 & 123.86 & 21.67 & 7.21 & 4.34 & 4.88 & 34.50 \\
\hline $\begin{array}{l}\text { Stickchut 4\%+ } \\
\text { Groplantofix } \\
\text { 400 mg / L }\end{array}$ & 78.91 & 125.00 & 23.50 & 5.90 & 4.46 & 4.95 & 35.21 \\
\hline L. S. D. 0.05 & 1.12 & 1.80 & 1.46 & 1.30 & 0.09 & 0.06 & 0.43 \\
\hline
\end{tabular}

Table 2

Effect of spraying with Stickchut and Groplantofix and their interaction on physical and chemical characters fruits of local fig cv. Aswod Diala for season 2015.

\begin{tabular}{|l|l|l|l|l|l|l|l|}
\hline Treatments & $\begin{array}{l}\text { firmness of } \\
\text { fruit kg/cm }\end{array}$ & $\%$ cracking & $\begin{array}{l}\% \\
\text { humidity } \\
\text { of fruits }\end{array}$ & $\begin{array}{l}\text { Total } \\
\text { yield Kg } \\
\text { /tree }\end{array}$ & $\begin{array}{l}\% \text { Total } \\
\text { soluble } \\
\text { sold }\end{array}$ & Acidity & Vitamin C \\
\hline \multicolumn{1}{|c|}{ Control } & 0.340 & 14.56 & 77.25 & 22.60 & 14.71 & 0.998 & 7.75 \\
\hline Stickchut 2\% & 0.350 & 13.15 & 77.81 & 23.57 & 14.65 & 0.996 & 7.60 \\
\hline Stickchut 4\% & 0.353 & 12.22 & 77.92 & 25.18 & 14.63 & 0.997 & 7.63 \\
\hline $\begin{array}{l}\text { Groplantofix } \\
\text { 300 mg / L }\end{array}$ & 0.364 & 9.95 & 78.23 & 28.74 & 14.50 & 0.994 & 7.56 \\
\hline $\begin{array}{l}\text { Groplantofix } \\
\text { 400 mg / L }\end{array}$ & 0.375 & 8.57 & 78.20 & 29.45 & 14.43 & 0.990 & 7.43 \\
\hline $\begin{array}{l}\text { Stickchut 2\%+ } \\
\text { Groplantofix } \\
\text { 300 mg / L }\end{array}$ & 0370 & 8.60 & 78.74 & 28.90 & 14.31 & 0.985 & 7.52 \\
\hline
\end{tabular}




\begin{tabular}{|l|l|l|l|l|l|l|l|}
\hline $\begin{array}{l}\text { Stickchut 2\%+ } \\
\text { Groplantofix } \\
\text { 400 mg / L }\end{array}$ & 0.386 & 8.13 & 79.11 & 30.33 & 14.28 & 0.981 & 7.32 \\
\hline $\begin{array}{l}\text { Stickchut 4\%+ } \\
\text { Groplantofix } \\
300 \text { mg / L }\end{array}$ & 0.412 & 7.89 & 79.23 & 30.62 & 14.20 & 0.991 & 7.26 \\
\hline $\begin{array}{l}\text { Stickchut 4\%+ } \\
\text { Groplantofix } \\
\text { 400 mg / L }\end{array}$ & 0.423 & 6.59 & 80.01 & 31.48 & 14.17 & 0.978 & 7.18 \\
\hline L.S. D. 0.05 & 0.09 & 1.03 & 0.19 & 0.95 & 0.10 & n.s & 0.09 \\
\hline
\end{tabular}

\section{References:}

1. Abo-Zaid AN (2000) Plant Hormones and Application Agricultural. Arabic home for putolishing. Cairo.

2. Abdlecho SH (2013) Effect of spraying Grofalcs and Wilt- Pruf on quality characters of fruits local trees pomegranate. J. AL-Kufa Univ .For Biology. 2 ( 5 ) : $1-5$.

3. AL-Eneabi RM (2008) The effect of spraying NAA, $\mathrm{CaCl} 2$ and Vapor-Gard on the vegetative growth, specific and Storage Gravity of Fig Fruits c.v. Asowd Diala (ficus carica L.). M.Sc. D.Thesis. Dep. Hort. Agric. Colle. Univ.of Kufa .Iraq.

4. AL-Ebraheme AA (2013) Effect of spraying with Stavals and castor oil on quality of local apple cv. Read summer tress. Journal of Babylon. 2 (21 ): 694-698 .

5. AL-Hameedawi AM (2015) Response of local apple trees to spraying with Grofalcs, Stavals and Tall- Prolong on physical and chemical characteristics of fruits. ISJ Theoretical and Applied Science. 9 (29): 72-75.

6. AL-Hameedawi AM, Ali HJ, AL-Mousawy NS (2014) Effect of pruning and spraying Grofalcs and Zeatin on some vegetative growth and yield, and its quality of fig tree cv. "Waziri" (Ficuscarica L.). International Journal for Sciences and Technology ( IJST ). 9(2) : 7-11.

7. AL-Hamdawi AM, AL-Numani RM (2012) Effect of Pruning and spraying with Paclobutrazol and Zinc sulphate on fruits quality of fig cv. Asowd Diala and percentage of cracking. The international Journal for Sciences and Technology ( IJST ). 7 ( 4 ) : 5 10.

8. AL-Numani RM (2013) Effect of Salicylic acid and Grofalcs on physical and chemical characteristics of local apple fruits ( Maluspumila M . ). J . ALphrat of Agricultural Scions . 5 ( 1 ) :34-39.
9. AL-Rawi KM, Khalf Allah AM (2000) Design and Analysis of Agricultural Experiments. College of Agric. Univ. Mosel. Iraq.

10. AL-Uajjani ZA (2011) Effect of Pruning and spraying of some of regulators on growth and yield of fig trees ( Ficus carica L . ) c.v. Aswad Diala . M.Sc . D. Thesis . Dep. Hort. Agric. Colle. Univ.of Kufa .Iraq.

11. A.O.A.C. (1985) Association of Official Analytical Chemist. Official Methods of Analysis .13 ${ }^{\text {th }}$ Ed. APAC . Washington. D.C.

12. Byers RE, Carbough HD (1995) Chemical, Cultural and physiological factors influencing Stayman fruit cracking. Virginia polytechnic Institute and State University Bulletin . 95 (1): 1-33.

13. Hayat I, Masud T, Rathore HA (2003) Effect of coating and wrapping materials on the shelf life of apple (Malus domestica c.v. Borkh). Department of Food Technology, University of Arid Agriculture, Rawalpindi.

14. Ibrahim HM (2010) Collection and Analysision of plant sample. Univ. Mena.Dar AL-Fager for publication and distribution. Egypt.

15. Jundi HM (2003) Physiology of tree fruits. Arabic home for putolishing. Cairo.

16. Sabir SM, Shah ZA, Fzal AA (2004) Effect of Chemical treatment, wax coating, oil dipping and different wrapping materials on physiological and chemical characteristics and storage behavior of apple Malas domestica, L. Bork . Pakistan J. of nutr. 3 (2):122-127. 